\title{
Development and Evaluation of Fast Disintegrating Tablets of Ondansetron with Natural and Synthetic SuperDisintegrating Agents
}

\author{
Latha Uppala ${ }^{1 *}$ and Palle Pranusha ${ }^{2}$ \\ ${ }^{1}$ Department of Pharmaceutics, SSJ College of pharmacy, Hyderabad, India \\ ${ }^{2}$ Department of Pharmacology, Gokaraju Rangaraju College of pharmacy, Hyderabad, India
}

Received: June 12, 2015; Accepted: July 30, 2015; Published: August 20, 2015

*Corresponding author: Latha Uppala, Department of Pharmaceutics, SSJ College of Pharmacy, Hyderabad, India, E-mail: chowdarylatha79@gmail.com

\begin{abstract}
Ondansetron a widely prescribed anti-ulcer drug belongs to BCS class II and exhibit low and variable oral bioavailability due to its poor solubility and dissolution rate and having high permeation rate. In the present work, oral disintegrating tablets of Ondansetron were developed with a view to enhance the patient compliance and provide quick onset of action. Ondansetron is a serotonin 5-HT3 receptor antagonist used mainly as an anti-emetic (to treat nausea and vomiting).

It affects both peripheral and central nerves. Ondansetron reduces the action of the vagus nerve, which deactivate the vomiting centre, and also block serotonin receptors in the chemoreceptor trigger zone. It has slight effect on vomiting caused by motion sickness, since drug is highly bitter.

The drug solid dispersed coated granules showed no bitterness in the taste. Oral disintegrating tablets prepared by direct compression method using super disintegrants like cross povidone, cross carmellose sodium, sodium starch glycolate, in different concentrations and evaluated for the pre-compression parameters such as bulk density, compressibility and angle of repose.
\end{abstract}

The arranged batches of tablets were evaluated for hardness, weight variation, thickness, friability, drug content, disintegration time and invitro dissolution profile and found satisfactory.

Aim: The aim of the present study is to formulate and evaluate fast disintegrating tablets of Ondansetron by direct compression method employing super disintegrating agents.

The objective of present study:

- The purpose of this research was to mask the strongly bitter taste of Ondansetron HCL and to formulate a rapid - disintegrating tablet.

- To formulate an orally disintegrating tablet so that it can be administered to paediatric and geriatric patients.

\section{Introduction}

\section{Fast Dissolving Tablets}

United States Food and drug administration (FDA) defined fast dissolving tablet (FDT) as "a solid dosage form containing medicinal substance or active ingredient which disintegrate fast usually within a few seconds when placed upon the tongue."

FDTs differ from traditional tablets as they are designed to be dissolved on the tongue rather than swallowed whole.

Fast dissolving tablets are also known as mouth-dissolving tablets, melt-in mouth tablets, Orodispersible tablets, porous tablets, quick dissolving tablets, fast dissolving tablets.

According to US Food and Drug Administration 2008 publications of guidance are:

1. FDTs should have an In vitro disintegrating time of approximately $30 \mathrm{sec}$ or less (using United States Pharmacopeia disintegration test or equivalent).
2. Generally, the FDT tablet weight should not exceed 500 $\mathrm{mg}$, although the combined influence of stable weight, size and component solubility all factor into the acceptability of an ODT for both patients and regulators.

3. The guidance serves to define the upper limits of the FDT category, but it does not replace the original regulatory definition mentioned.

\section{Materials and Methods}

Drug description (Fig no 1)<smiles></smiles> 


$$
\mathrm{C}_{18} \mathrm{H}_{19} \mathrm{~N}_{3} \mathrm{O}
$$

IUPAC name: 9-methyl-3-[(2-methylimidazol-1-yl)methyl]-

2,3-dihydro-1H-carbazol-4-one

\section{Generic name: Ondansetron}

Brand name: Vomikind

Description: White powder, crystalline

Melting point: $231-232^{\circ} \mathrm{C}$

Molecular weight: $293.36296 \mathrm{~g} / \mathrm{mol}$.

Category: Anti-emetic

\section{Materials Used (Table 1)}

\section{Equipments used}

Equipments used in the formulation are listed below:

- Electronic digital balance

- $\quad$ Sixteen station rotary tablet punching machine

- $\quad$ Pfizer hardness tester

- $\quad$ Friability tester

- Disintegration apparatus

- Dissolution apparatus

- Double beam UV-spectrophotometer

\section{Methods}

\begin{tabular}{|l|l|l|}
\hline \multicolumn{2}{|l|}{ Table 1: } & \multicolumn{1}{|c|}{ Cxcipients used. } \\
\hline \multicolumn{1}{|c|}{ S.no } & \multicolumn{1}{|c|}{ Ingredients } & \multicolumn{1}{|c|}{ Category } \\
\hline 1. & Microcrystalline cellulose & Diluents \\
2. & Mannitol & Sweetening agent \\
3. & Crosscarmellose sodium & Super disintegrant \\
4. & Ispaghula husk & Natural Superdisintegrant \\
5. & Sodium starch glycolate & Super disintegrant \\
6. & Sodium saccharine & Artificial sweetener \\
7. & Magnesium stearate & Lubricant \\
8. & Talc & Glidant \\
\hline
\end{tabular}

\section{Pre formulation studies}

Angle of repose: The resistance forces in a free powder can be measured by the angle of repose $(\theta)$. It is an symptomatic of the flow properties of the powder. It is known as maximum angle possible between the surface of the mound of powder and the horizontal plane (Table 2).

$$
\begin{aligned}
& \tan (\theta)=\mathrm{h} / \mathrm{r} \\
& \theta=\tan -1(\mathrm{~h} / \mathrm{r})
\end{aligned}
$$

\begin{tabular}{|c|c|c|}
\hline \multicolumn{3}{|c|}{ Table 2: Angle of Repose for Powder Flow Properties. } \\
\hline Sr. No. & Angle of Repose $\mathbf{~}^{\circ} \mathbf{)}$ & Type of Flow \\
\hline 1 & $<20$ & Excellent \\
\hline 2 & $20-30$ & Good \\
\hline 3 & $30-34$ & Passable \\
\hline 4 & $>34$ & Very Poor \\
\hline
\end{tabular}

Where, $\theta$ is the angle of repose

$\mathrm{h}$ is the height in $\mathrm{cms}$

$\mathrm{r}$ is the radius in cms.

Bulk Density $\left(\mathbf{D}_{\mathbf{b}}\right)$ : It is measured by pouring the powder (passed through standard sieve \# 20) into a measuring cylinder, the initial weight was noted. This initial volume is called the bulk volume. The bulk density is calculated according to the formula mentioned below. It is expressed in $\mathrm{g} / \mathrm{ml}$ and is given by

$\mathrm{D}_{\mathrm{b}}=\mathrm{M} / \mathrm{V}_{\mathrm{b}}$

Where, $\mathrm{M}$ is the mass of powder

$\mathrm{V}_{\mathrm{b}}$ is the bulk volume of the powder.

Tapped Density ( $\mathbf{D}_{\mathbf{t}}$ ): Volume measured by tapping the powder for 100 times and the tapped volume was noted if the difference between these two volumes is less or more than $2 \%$, tapping is continued for 1250 times and noted. Tapping was continued until the successive volumes are less than $2 \%$ (in a bulk density apparatus). It is expressed in $\mathrm{g} / \mathrm{ml}$ and is given by

$\mathrm{D}_{\mathrm{t}}=\mathrm{M} / \mathrm{V}_{\mathrm{t}}$

Where, $\mathrm{M}$ is the mass of powder

$\mathrm{V}_{\mathrm{t}}$ is the tapped volume of the powder.

Hausner's ratio: Hausner's ratio is an indirect index of ease of powder flow. It is calculated by following formula (Table 3).

Hausner's ratio $=D_{t} / D_{b}$

Where, $\mathrm{D}_{\mathrm{t}}$ is tapped density.

$\mathrm{D}_{\mathrm{b}}$ is bulk density.

Compressibility index: The compressibility index (Carr's Index) was determined by using following equation (Table 4).

Carr's Index $(\%)=\left[\left(D_{t}-D_{b}\right) \times 100\right] / D_{t}$

Where, $D_{t}$ is the tapped density of powder

$D_{b}$ is the bulk density of powder.

Formulation development (Table 5): Method of formulation: Fast disintegrating tablets of ondansetron $\mathrm{Hcl}$ containing different concentrations of super disintegrants were prepared by direct compression method all the ingredients without magnesium stearate and talc were sifted through the sieve \#44 and are mixed for about $15 \mathrm{~min}$ to make a uniform blend. Magnesium stearate and talc were passed through sieve \#60 and mixed with above powder for sufficient time, usually 5-7mins. 
Table 3: Relationship between flow characters and Hausner's ratio.

\begin{tabular}{|c|c|}
\hline Flow Character & Hausner's Ratio \\
\hline Excellent & $1.00-1.11$ \\
\hline Good & $1.12-1.18$ \\
\hline Fair & $1.19-1.25$ \\
\hline Passable & $1.26-1.34$ \\
\hline Poor & $1.35-1.45$ \\
\hline Very Poor & $1.46-1.59$ \\
\hline Very Very Poor & $>1.60$ \\
\hline
\end{tabular}

Table 4: Relationship between \% compressibility and flow ability.

\begin{tabular}{|c|c|}
\hline \% Compressibility & Flow ability \\
\hline $5-12$ & Excellent \\
$12-16$ & Good \\
$18-21$ & Fair passable \\
$23-35$ & Poor \\
$33-38$ & Very poor \\
$<40$ & Very very poor \\
\hline
\end{tabular}

The prepared powder were evaluated for various pre formulation parameters like bulk density, tapped density ,angle of repose, carr's index and Haunser ratio and compressed using sixteen station rotary tableting machine. Finally all the evaluation tests were conducted.

\section{Evaluation tests}

Weight variation: Tablets are considered to contain a definite amount of drug in a specific amount of tablet formula; the weight of the tablet is measured to help in such a way that the tablet contains the accurate amount of drug. Average weight of 20 tablets were selected randomly from the lot and weighed individually to check for weight variation (Table 6)

Thickness: The thickness of pre-weighed 10 tablets of each formula was measured using a micrometer. It is measured by placing it between two anvils and rotating the sliding knob until the tablet was tightly fitted and the reading was noted. The tablet thickness should be controlled within a $\pm 5 \%$ variation of a standard value.

Hardness: Hardness or tablet crushing strength, the force required to break a tablet in a diametric compression was measured using Monsanto tablet hardness tester. It is measured in $\mathrm{kg} \mathrm{cm}^{2}$. Usual range of hardness for conventional tablets is 4-6 $\mathrm{kg} / \mathrm{cm}^{2}$. The hardness for FDTs should be preferably $2-3 \mathrm{~kg} / \mathrm{cm}^{2}$.

Friability (F): Friability of the tablet is determined using Roche friabilator. This device subjects the tablet to the combined effect of abrasion and shock in a plastic chamber revolving at 25 rpm and dropping a tablet at a height of 6 inches in each revolution. Pre weighed sample of tablets was placed in the friabilator and were subjected to the 100 revolutions. Tablets were dusted using a soft muslin cloth and reweighed. The friability (F) is given by the formula.

$$
F=\frac{W_{\text {initial }}-W_{\text {final }}}{W_{\text {initial }}} \times 100
$$

Wetting time: Tissue paper folded and placed in a Petri plate (internal diameter is $6.5 \mathrm{~cm}$ ) containing $6 \mathrm{ml}$ of water. The tablet was placed on the paper and the time for complete wetting of the tablet was measured in seconds. The method was slightly modified by maintaining water at $37^{\circ} \mathrm{C}$.

Disintegration time: According to this method, a Petri dish of $10 \mathrm{~cm}$ diameter was filled with $10 \mathrm{ml}$ of distilled water, the tablet was carefully placed at the centre of the Petri dish, and the time necessary for the complete disintegration of the tablet into fine particles was noted as disintegration time.

Dissolution studies: Tablet test condition for the dissolution rate studies were used according to USP specification using USP type II apparatus. The dissolution medium was $900 \mathrm{ml}$ of $0.1 \mathrm{~N} \mathrm{HCl}(\mathrm{pH} \mathrm{1.2)}$. The temperature of the dissolution medium and the rate of agitation were maintained at $37^{\circ} \pm 0.5^{\circ} \mathrm{C}$ and $50 \mathrm{rpm}$ respectively. Aliquots of $10 \mathrm{ml}$ of dissolution medium were withdrawn at specific time intervals and the volume was replaced by fresh dissolution medium, pre warmed to $37^{0} \pm 0.5^{\circ} \mathrm{C}$. The drug concentration was determined spectrophotometrically

Table 5: Formula used in formulation of ondansetron Hcl fast disintegrating tablets.

\begin{tabular}{|c|c|c|c|c|c|c|c|c|c|}
\hline Ingredients & $\begin{array}{c}\text { F1 } \\
\text { (mg) }\end{array}$ & $\begin{array}{c}\text { F2 } \\
\text { (mg) }\end{array}$ & $\begin{array}{c}\text { F3 } \\
\text { (mg) }\end{array}$ & $\begin{array}{c}\text { F4 } \\
\text { (mg) }\end{array}$ & $\begin{array}{c}\text { F5 } \\
\text { (mg) }\end{array}$ & $\begin{array}{c}\text { F6 } \\
\text { (mg) }\end{array}$ & $\begin{array}{c}\text { F7 } \\
\text { (mg) }\end{array}$ & $\begin{array}{c}\text { F8 } \\
(\mathrm{mg})\end{array}$ & $\begin{array}{c}\text { F9 } \\
\text { (mg) }\end{array}$ \\
\hline Ondansetron $\mathrm{Hcl}$ & 4 & 4 & 4 & 4 & 4 & 4 & 4 & 4 & 4 \\
\hline Crosscarmellose sodium & - & - & - & 6 & 8 & 10 & - & - & - \\
\hline Ispaghula husk & - & - & - & - & - & - & 6 & 8 & 10 \\
\hline Microcrystalline cellulose & 200 & 198 & 196 & 200 & 198 & 196 & 200 & 198 & 196 \\
\hline Sodium saccharin & 2 & 2 & 2 & 2 & 2 & 2 & 2 & 2 & 2 \\
\hline Magnesium stearate & 2 & 2 & 2 & 2 & 2 & 2 & 2 & 2 & 2 \\
\hline Talc & 6 & 6 & 6 & 6 & 6 & 6 & 6 & 6 & 6 \\
\hline Total & 300 & 300 & 300 & 300 & 300 & 300 & 300 & 300 & 300 \\
\hline
\end{tabular}


Table 6: Weight Variation Limits for Tablets (I.P).

\begin{tabular}{|c|c|}
\hline Average Weight of Tablet & \% Deviation \\
\hline $80 \mathrm{mg}$ or less & \pm 10 \\
\hline More than $80 \mathrm{mg}$ but less than $250 \mathrm{mg}$ & \pm 7.5 \\
\hline $250 \mathrm{mg}$ or more & \pm 5 \\
\hline
\end{tabular}

at $249 \mathrm{~nm}$ using UV spectrophotometer.

\section{Results and Discussions}

\section{Pre formulation studies (Table 7)}

Organoleptic and flow properties: Various Organoleptic and flow properties studies have been done and the results are based on standard given. Therefore pre formulation values are within the limits.

Evaluation tests of ondansetron fast disintegrating tablets(Table 8):

- The hardness was found to be in the range of 2.5 to 3.0 $\mathrm{kg} / \mathrm{cm}^{3}$.

- Tablet thickness was maintained between 2.14 to 2.86 $\mathrm{cm}$.

- The friability was found to less than $1 \%$ was indication of good mechanical resistance of tablets.

- As the powder was free flowing tablets produced were of uniform weight with acceptable weight variation $(\leq$ $1.19 \%$ ) due to uniform die fill.

Standard graph of ondansetron Hcl (Table 9): The absorbance of above solutions was recorded at $\lambda_{\max }(249 \mathrm{~nm})$ of the drug using double beam UV -visible spectrophotometer. Standard graph was plotted between the concentration (on $\mathrm{X}$-axis) and absorbance (on Y-axis) (Fig no 2).

A spectrum of the working standards was obtained by scanning from 200-400 $\mathrm{nm}$ by UV double beam spectrophotometer against the reagent blank to fix absorption maxima. The $\lambda_{\max }$ was found to be $249 \mathrm{~nm}$. Hence all further investigation was carried out

Table 7: Flow properties.

\begin{tabular}{|c|c|c|c|c|c|}
\hline Code & Angle of repose $(\theta)$ & $\begin{array}{l}\text { Bulk density } \\
\left(\mathrm{gm} / \mathrm{cm}^{3}\right)\end{array}$ & Tapped Density $\left(\mathrm{gm} / \mathrm{cm}^{3}\right)$ & Carr's index(\%) & Hausner Ratio \\
\hline$F_{1}$ & 34.6 & 0.40 & 0.663 & 15.610 & 1.235 \\
\hline $\mathbf{F}_{2}$ & 37.2 & 0.46 & 0.701 & 15.730 & 1.811 \\
\hline $\mathbf{F}_{3}$ & 29.6 & 0.35 & 0.698 & 15.919 & 1.177 \\
\hline $\mathbf{F}_{4}$ & 38.6 & 0.43 & 0.695 & 14.155 & 1.177 \\
\hline $\mathbf{F}_{5}$ & 35.3 & 0.42 & 0.696 & 14.864 & 1.178 \\
\hline $\mathbf{F}_{6}$ & 35.7 & 0.43 & 0.694 & 11.697 & 1.787 \\
\hline $\mathbf{F}_{7}$ & 31.3 & 0.42 & 0.698 & 13.242 & 1.160 \\
\hline$F_{8}$ & 29.6 & 0.47 & 0.700 & 12.528 & 1.141 \\
\hline$F_{9}$ & 39.6 & 0.43 & 0.822 & 14.325 & 1.162 \\
\hline
\end{tabular}

Table 8: Evaluation tests of Ondansetron Hcl fast disintegrating tablets.

\begin{tabular}{|c|c|c|c|c|c|c|}
\hline Code & $\begin{array}{l}\text { Hardness } \\
\left(\mathrm{kg} / \mathrm{cm}^{2}\right)\end{array}$ & $\begin{array}{c}\text { Thickness } \\
\text { (cm) }\end{array}$ & Friability\% & Weight variation(mg) & $\begin{array}{l}\text { Wetting } \\
\text { time(sec) }\end{array}$ & Disintegration time (sec) \\
\hline $\mathrm{F}_{1}$ & 2.8 & 2.24 & $0.27 \%$ & 100.02 & $35 \mathrm{sec}$ & $24 \mathrm{sec}$ \\
\hline $\mathrm{F}_{2}$ & 3.0 & 2.14 & $0.13 \%$ & 100.05 & $41 \mathrm{sec}$ & $30 \mathrm{sec}$ \\
\hline $\mathrm{F}_{3}$ & 2.6 & 2.34 & $0.87 \%$ & 100.03 & $39 \mathrm{sec}$ & $25 \mathrm{sec}$ \\
\hline $\mathrm{F}_{4}$ & 2.7 & 2.55 & $0.21 \%$ & 100.04 & $41 \mathrm{sec}$ & $28 \mathrm{sec}$ \\
\hline $\mathrm{F}_{5}$ & 3.0 & 2.67 & $0.28 \%$ & 100.01 & $43 \mathrm{sec}$ & $29 \mathrm{sec}$ \\
\hline $\mathrm{F}_{7}$ & 3.0 & 2.30 & $0.54 \%$ & 100.01 & 30 se c & $33 \mathrm{sec}$ \\
\hline $\mathrm{F}_{8}$ & 2.5 & 2.56 & $0.20 \%$ & 100.03 & $27 \mathrm{sec}$ & $35 \mathrm{sec}$ \\
\hline $\mathrm{F}_{9}$ & 3.0 & 2.38 & $0.42 \%$ & 100.06 & $27 \mathrm{sec}$ & $36 \mathrm{sec}$ \\
\hline
\end{tabular}

Table 9: Standard graph of Ondansetron Hcl.

\begin{tabular}{|c|c|}
\hline Concentration $(\mu \mathrm{g} / \mathrm{ml})$ & Absorbance \\
\hline 0 & 0 \\
\hline 2 & 0.14 \\
\hline 4 & 0.28 \\
\hline 6 & 0.42 \\
\hline 8 & 0.56 \\
\hline 10 & 0.71 \\
\hline
\end{tabular}




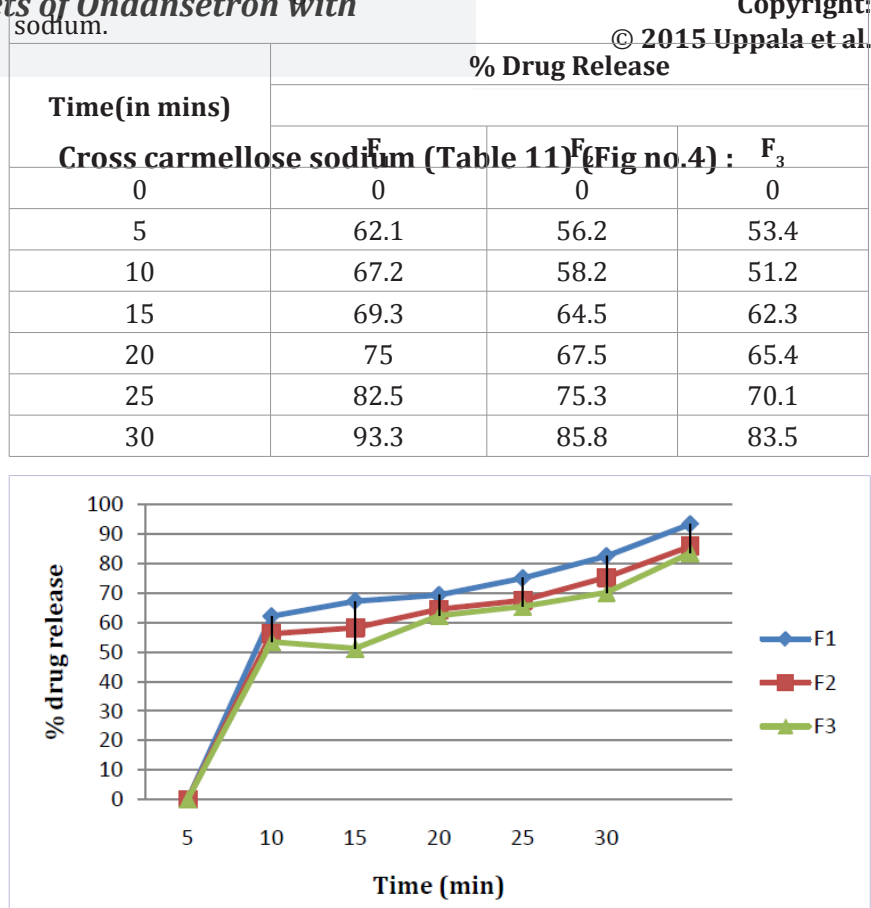

Figure 4: Graph plotted between concentration and absorbance with CCS.

Ispaghula husk (Table 12) (Fig no 5):

Table 12: Invitro drug release of Ondansetron with ispaghula husk.

\begin{tabular}{|c|c|c|c|}
\hline \multirow{2}{*}{ Time( in mins) } & \multicolumn{3}{|c|}{ \% Drug Release } \\
\cline { 2 - 4 } & $\mathbf{F}_{\mathbf{1}}$ & $\mathbf{F}_{\mathbf{2}}$ & $\mathbf{F}_{\mathbf{3}}$ \\
\hline 0 & 0 & 0 & 0 \\
\hline 5 & 72.3 & 67.3 & 64.2 \\
\hline 10 & 75.6 & 70.1 & 68.8 \\
\hline 15 & 79.9 & 75.3 & 72.6 \\
\hline 20 & 82.6 & 77.1 & 74.3 \\
\hline 25 & 90.8 & 81.2 & 79.5 \\
\hline 30 & 95.3 & 90.4 & 86.3 \\
\hline
\end{tabular}

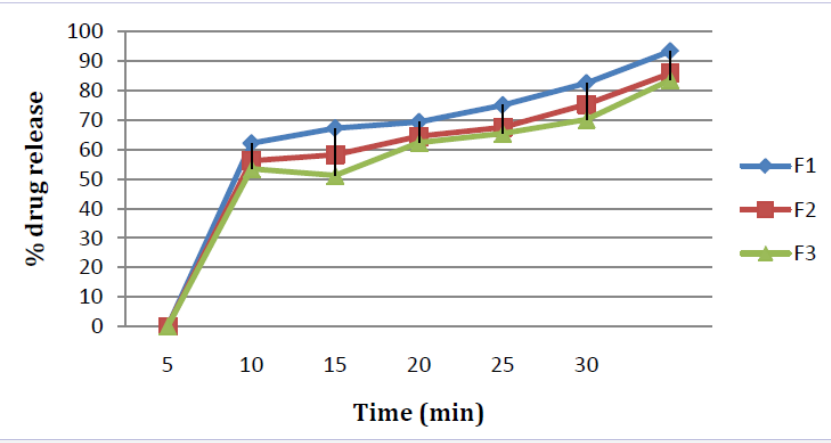

Figure 5: Graph plotted between concentration and absorption with ispaghula husk.

\section{Conclusion}

Fast disintegrating tablets have possible advantages over usual dosage forms, with improved patient observance, convenience, bioavailability and rapid onset of action. They are good substitute for drug delivery to geriatric and paediatric patients. They have major advantages of both solid and liquid dosage forms, as they remain solid during storage, which assist in stability of dosage forms and transform into liquid form within

Figure 3: Graph plotted between concentration and absorbance with SSG. 
few seconds after its administration Thus FDT has great scope for being immediate drug delivery.

All the formulation was evaluated for bulk density, tapped density, Hauser's ratio, compressibility index and angle of repose. As the powder was free flowing, tablets produced were of uniform weight with acceptable weight variation $(\leq 1.19 \%)$ due to uniform die fill. Thus the observation of the study can be summarized as

- Tablet prepared by direct compression method were found to be good, without any chipping, sticking and capping.

- The hardness was found to be in the range of 2.5 to 3.0 $\mathrm{kg} / \mathrm{cm}^{3}$.

- $\quad$ Tablet thickness was maintained between 2.14 to 2.86 $\mathrm{cm}$.

- The friability was found to less than $1 \%$ was indication of good mechanical resistance of tablets.

It is concluded that the formulated fast disintegrating tablets of ondansetron using sodium starch glycolate was capable of exhibiting immediate release properties. Among all the formulations F-1 prepared with sodium starch glycolate in concentration $6 \%$ as super disintegrant exhibit least disintegration time $(24 \mathrm{sec})$ and showed maximum drug release of $98.1 \%$ within 30 mins. As the concentration of super disintegrant in the formulations increased the disintegration time was found to decrease. From the characterisation of fast disintegrating tablets of ondansetron it can be concluded that formulation containing sodium starch glycolate $6 \%$ is most acceptable.

\section{References}

1. Britto MR, Hussey EK, Mydlow P, J R Powell, K L R Brouwer. Effect of enzyme inducers on ondansetron (OND) metabolism in humans. Clin Pharmacol Ther. 1997;61(2):228.

2. Pugh RNH, Murray-Lyon IM, Dawson JL, Pietroni MC, Williams R. Transection of the oesophagus for bleeding oesophageal varices. Brit J Surg. 1973;60(8):646-649.

3. Villikka K, Kivisto KT, Neuvonen PJ. The effect of rifampin on the pharmacokinetics of oral and intravenous ondansetron. Clin Pharmacol Ther. 1999;65(4):377-381.

4. De Witte JL, Schoenmaekers B, Sessler DI, Deloof T. The analgesic efficacy of tramadol is impaired by concurrent administration of ondansetron. Anesth Analg. 2001;92(5):1319-1321.

5. Arcioni R, della Rocca M, Romanò R, Pietropaoli $\mathrm{P}$, Gasparetto A,Romanò S. Ondansetron inhibits the analgesic effects of tramadol: a possible 5-HT(3) spinal receptor involvement in acute pain in humans. Anesth Analg. 2002;94(6):1553-1557.

6. Bandari S. Orodispersible tablets: An overview. Asian J. Pharm. 2008;2(1):2-11.

7. Abdelbary G, Eouani C, Prinderre P, Joachim J, Reyneir J. Determination of the in-vitro disintegration profile of rapidly disintegrating tablets and correlation with oral disintegration. Int. J. Pharm. 2005;292(12):29-41.

8. LeBourgeois JP, McKenna CJ, Coster B, Feyer P, Franzén L, Goedhals L, et al. Efficacy of an Ondansetron orally disintegrating tablet: a novel oral formulation of this 5-HT3 receptor antagonist in the treatment of fractionated radiotherapy induced nausea and emesis. Clinical oncology. 1999;11(5):340-347.

9. Khan S, Kataria P, Nakhat P, Yeole P. Taste masking of Ondansetron Hydrochloride by polymer carrier system and formulation of rapid disintegrating tablets. AAPS Pharm SciTech. 2007;8(2):E1-E7.

10. Ahmed SU, Sudhir RG, Tahseen AC. Ondansetron orally disintegrating tablets. US Patent No. 7390503. 2008.

11. Adamo F, Valentina Bergamante, Gian Carlo Ceschel, Celestino Ronchi, Carlos Alberto, Fonseca de Moraes. Fast dispersible/slow releasing Ibuprofen tablets. Eur. J. Pharm. and Biopharm. 2008;69(1):335-341.

12. Sameer GL, Yu YY, Banga AK. Effects of disintegration promoting agent lubricants and moisture treatment on optimized fast disintegrating tablets. Int. J. Pharm. 2009;365(1-2):4-11. doi:10.1016/j. ijpharm.2008.08.010.

13. Chandrasekhar R, Hassan Z, Alhusban F, Smith AM, Mohammed AR. The role of formulation excipients in the development of lyophilized fastdisintegrating tablets. Eur. J. Pharm. and Biopharm. 2009;72(1):119129. doi: $10.1016 /$ j.ejpb.2008.11.011.

14. Yara PA, Schramm SG, Silva Mde F, Kano EK, Koono EE, Porta V, et al. Bioequivalence assay between orally disintegrating and conventional tablet formulations in healthy volunteers. Int. J. Pharm. 2009;366(12):149-153. doi:10.1016/j.ijpharm.2008.09.021.

15. Sradhanjali P, AA Choudhury, RK Kar, BB Barik. Spectrophotometric method for Ondansetron hydrochloride. Ind. J. Pharm.Sci. 2007;69(6):840-841.

16. Qalaji-Rawas MM, Simons ER, Simons KJ. Fast disintegrating sublingual tablets: Effect of Ephinephrine load on tablet characteristic. AAPS PharmSciTech. 2006;7(2):E41.

17. Hanawa T, Watanabe A, Tsuchiya T, Ikoma R, Hidaka M, Sugihara M. New oral dosage form for elderly patients: preparation and characterization of silk fibroin gel. Chem Pharm Bull. 1995;43(2):284288.

18. Watanable Y, Ishikawa Y, Utoguchi N, Matsumoto M. Preparation and evaluation of tablets rapidly disintegrating in saliva containing bitter taste masked granules by the compression method. Chem. Pharm. Bull. 1999;47(1999):1451-1457. doi.10.1248.cpb.47.1451

19. Kaushik D, Dureja H, Saini TR. Mouth dissolving tablets: A review. Indian Drugs Bombay. 2004;41(4):187-193.

20. Ashok RP, Pradeep RV. Preparation and evaluation of taste masked famotidine formulation using drug/ß- cyclodextrin/polymer ternary complexation approach. AA PS Pharm SciTech. 2008;9(2):544-550. doi: 10.1208/s12249-008-9078-0.

21.Jhonson BA, Roache JD, Javors MA, Carlo C. DiClemente, Claude Robert Cloninger,Thomas J Prihoda, et al. Ondanseton for reduction of drinking among biologically predisposed alcoholic patients. JAMA. 2000;284(8):963-971. doi:10.1001/jama.284.8.963.

22. Dobetti L. Fast-melting tablets: Developments and technologies. PharmTechnol Eur. 2000;12(9):32-42.

23. Mizumoto T, Masuda Y, Takeshi Y, Estuo Y, Katsuhide T. Formulation design of a novel fast-disintegrating tablet. Int J Pharm. 2005;306(12):83-90.

24. Zhao N, Augsburger LL. Functionality comparison of 3 classes of super disintegrants in promoting aspirin tablet disintegration and dissolution. AAPS Pharm Sci Tech. 2005;6(4):634-640. 
25. Sunil HM, Patel LD, Tejas B, Timir B Patel, Tushar R Patel. Formulation and Evaluation of Taste Masked Orodispersible Tablets of Ondansetron Hydrochloride. Jounral of Pharmaceutical Science \& Research. 2010;2(4):232-239.

26. Anton Smith, Kottai Muthu A, Pandit WB, R Manavalan. Formulation Development and Evaluation of Ondansetron Hydrochloride sustained release Matrix tablets. Journal of Pharmaceutical Science \& Research. 2009;1(4):48-54.

27. Praveen KM, Rajendra PM, Pramod M, V Prabhakar Reddy. Effect of Permeation Enhancer On Ex-Vivo Permeation Of Ondansetron Hcl Buccal Tablets. International Journal Of Research Of Pharmaceuticals Science And Research. 2011;2(11):2841-2845

28. Hony G, Nishant V, Ashok A, Rana V. Formulation Of Orodispersible
Tablet Of Ondansetron Hydrochloride: Investigation Using GlycineChistosen Mixture As Superdisintegrant. Yakugaku Zasshi. 2009;129(5):513-521.

29. Shagufta K, Prashant K, Premchand N, Yeole P. Taste Masking Of Ondansetron Hydrochloride By Polymer Carrier System And Formulation Of Rapid-Disintegrating Tablets. Aaps Pharmaceutical Science Technology. 2007;8(2). 